\title{
Trench Inserts as Long-term Barriers to Root Transmission for Control of Oak Wilt
}

\author{
A. D. Wilson and D. G. Lester, USDA Forest Service, Forest Insect and Disease Research, Southern Research Sta- \\ tion, Center for Bottomland Hardwoods Research, Southern Hardwoods Laboratory, Stoneville, MS 38776-0227
}

\begin{abstract}
Wilson, A. D., and Lester, D. G. 2002. Trench inserts as long-term barriers to root transmission for control of oak wilt. Plant Dis. 86:1067-1074.

Physical and chemical barriers to root penetration and root grafting across trenches were evaluated for their effectiveness in improving trenches as barriers to root transmission of the oak wilt fungus in live oaks. Four trench insert materials were tested, including water-permeable Typar and Biobarrier, and water-impermeable Geomembrane of two thicknesses. Systemic fungicide treatments of trees immediately outside of trenches also were tested. In the first several years following trench installation, an abundance of small adventitious roots commonly formed from roots severed by trenching. These roots provided opportunities for initiation of root grafts across trenches in subsequent years. Although trench inserts did not significantly improve trenches during the first 3 years following trench installation, water-permeable inserts did effectively improve the performance of trenches beyond the third posttrenching year, when trenches are normally effective, and extended trench longevity indefinitely. The water-permeable inserts were more effective root barriers because they did not direct root growth from the point of root contact. The water-impermeable materials, however, did tend to direct root growth around these barriers, leading to the development of new root graft connections and associated oak wilt root transmission across the trench. The additional cost of trench inserts above trenching costs was justified in urban and rural homestead sites, where high-value landscape trees required more protection and additional retrenching costs were avoided.
\end{abstract}

Additional keywords: Ceratocystis fagacearum, cultural control, propiconazole, Quercus fusiformis, Quercus virginiana, trifluralin herbicide

Oak wilt, caused by Ceratocystis fagacearum (T.W. Bretz) J. Hunt, is a major vascular wilt disease that continues to shape the ecology of hardwood forest ecosystems of the eastern United States. Since oak wilt was first discovered in Wisconsin in 1942 (1), it has been considered by many to be the most serious disease of oak (Quercus sp.) in North America $(2,16,20)$. The oak wilt fungus is potentially the most destructive of all forest pathogens because few phytopathogenic microbes have greater capacity to kill their tree hosts with such rapidity $(16,23,38)$. The impact of the disease on oak forests in the United States

Corresponding author: A. D. Wilson

E-mail: dwilson02@fs.fed.us

Mention of a proprietary product or service does not constitute official endorsement or recommendation by the U.S. Department of Agriculture to the exclusion of others that may be suitable.

Accepted for publication 9 June 2002

Publication no. D-2002-0809-01R

This article is in the public domain and not copyrightable. It may be freely reprinted with customary crediting of the source. The American Phytopathological Society, 2002. has been exacerbated by changes in forest practices that have resulted in oak stands with greater proportions of susceptible red oak species $(16,29)$.

Oak wilt probably was first observed in Texas in the 1930s within the Hill Country or Edwards Plateau region. Unusually high live oak mortality was reported during this period in the Austin area $(24,25)$. The semievergreen live oaks, Quercus fusiformis Small (plateau live oak) and Quercus virginiana Miller (coastal live oak), are considered the most valuable woodland and urban tree species in central Texas (21). It appears that populations of the oak wilt fungus gradually developed within susceptible live oak stands over the next 40 years until they reached critical mass in the 1970s (29). The oak wilt epidemic that ensued continues to cause increasingly devastating losses to oak resources in Texas. Cumulative economic losses hitherto have been very conservatively estimated to be in the hundreds of millions of dollars statewide $(29,30)$. Such losses are easily rationalized given that a single large live oak can be worth up to $\$ 20,000$ to residential property values in metropolitan stand composition and forest management areas (13). Confirmed diagnoses of the disease have been reported in oaks from at least 61 of 254 Texas counties.

The practice of mechanically cutting root connections to control root transmission of the oak wilt fungus has been recommended for many years (18). Trenching to sever root connections between healthy trees in advance of the visible expanding edge of infection centers has long been the cornerstone of oak wilt suppression efforts both in Texas and in midwestern states with active control programs (29). Since 1988, the Texas Forest Service has administered the Texas Oak Wilt Suppression Project (TOWSP), which has installed over $650,000 \mathrm{~m}$ of trench to combat this disease (4). Trenching has been a particularly important tool for dealing with the disease in highly valued live oak stands because root grafts result in extensively interconnected root systems. This tendency is further compounded by the growth habit of live oaks in forming root sprouts from mother trees that often give rise to large clusters of clonal trees or "motts" with common root systems $(12,22,27)$. These natural growth tendencies increase the predisposition of live oaks to root transmission and have often resulted in dramatic mortality over very large areas. Red oaks such as Texas red oak or Spanish oak (Q. texana Buckley $=Q$. buckleyi Dorr \& Nixon), blackjack oak (Q. marilandica Münchh.), and Shumard oak ( $Q$. shumardii Buckley) are the most susceptible species to oak wilt in Texas, but disease incidence is greater in live oaks due to their growth-form predispositions and shallow, extensive root systems. The higher incidence of the disease in live oaks also may be attributed to their abundance in both urban and rural forests of central Texas. The predominance of live oaks has resulted from landscapemanagement practices involving fire suppression, preferential thinning, overgrazing, and selective protection of live oaks in this region $(2,7,12)$.

A 7-year study was initiated in 1993 to evaluate the efficacy of adding physical and/or chemical barriers to trenches for long-term control of root transmission of C. fagacearum in live oaks. The primary objectives of this study were to (i) test the usefulness of trench insert materials in preventing root penetrations and the development of new root graft connections 
across trenches, (ii) evaluate fungicide (propiconazole) treatments of trees immediately outside of trenches in preventing root transmission of the oak wilt fungus, and (iii) assess the capacity of all these barriers to provide long-term control of oak wilt root transmission. Since the time required for maturation of this study was unknown, interim results providing periodic assessments of barrier performance were reported previously (32-36).

\section{MATERIALS AND METHODS}

Research site and plot installation. Research was conducted on the 1,100-ha Circle C Ranch Land Development Tract located at the southern limits of Austin, TX, in Travis County. Plots were established in a mature natural stand of live oaks growing near a residential development site with a predominantly rocky, sandy clay-loam soil. Soil depth to bedrock ranged from 1.0 to $1.7 \mathrm{~m}$ at the test site. Test trees were selected approximately 25 to $30 \mathrm{~m}$ beyond the expanding edge of a large oak wilt infection center, previously determined to be a minimum buffer zone $(15,29)$. A roughly linear trench, established 27 July 1993, was cut approximately $1.6 \mathrm{~km}$ long and $1.5 \mathrm{~m}$ deep with a Vermeer turbo II trencher immediately adjacent to test trees and between test trees and the infection center. Selection of trench depth was based on soil depth, insert availability, and root penetration of soil $(27,37)$. The experimental design consisted of 18 sequential plots approximately 46 to $157 \mathrm{~m}$ long containing 12 to 18 test trees each situated along the full length of the trench. Trees within research plots were mapped for spatial calculations using a Criterion 400 survey laser (Laser Technology, Inc., Englewood, CO) and sequential-target mapping algorithms with polar Y plotting methods (28). Seven barrier treatments were applied to separate plots on 13 December 1993 in a completely randomized linear order along the trench with three replicate plots per treatment. The treatments included trenches with one of four trench inserts, no insert (trench only), trench with fungicide treatments of test trees outside of the trench, and no trench as untreated controls (Fig. 1). The three trench-only plots were established as semicircular bubbles around no-trench segments to maintain continuity to the trench barrier. Four trench-insert materials were tested, including water-permeable Typar polypropylene spunbonded fabric at $4 \mathrm{oz}$. (1x) weight; Biobarrier or Typar with trifluralin-impregnated 10-mm-diameter, controlled-release hemispherical pellets (54\% polyethylene, $18 \%$ carbon black, and $28 \%$ trifluralin by weight) bonded to polypropylene fabric with uniform $3.8-\mathrm{cm}$ spacing or 688 pellets per square meter (Reemay Inc., Old Hickory, TN); and water-impermeable polyethylene Rufco Geomembrane liners (Raven Industries, Springfield, $\mathrm{OH}$ ) of two thicknesses (20 and $30 \mathrm{mil}$ ). Trench inserts were placed into trenches in 15.2- or 30.5-m lengths, mounted with $15-\mathrm{cm}$ steel or aluminum pins to the wall of the trench on the side closest to the infection center, and additionally supported by backfilling the trench with soil removed during construction of the trench, followed by leveling with a backhoe scoop blade (Fig. 2A to E).

Individual live oak trees within fungicide-treated plots received one of four fungicide applications: high-volume bole injections, low-volume bole injections with two types of microinjectors, and soil applications. All four fungicide application methods utilized the microencapsulated (blue) $14.3 \%$ EC formulation of propiconazole (Alamo) without xylene. Fungicide treatments were applied 23 to $27 \mathrm{Au}$ gust 1993 in a completely randomized linear sequence within fungicide-treated plots, each containing two to three replicate trees per treatment. All bole-injection methods applied the fungicide under pressure at 15 psi through injection ports, one port per $15.4 \mathrm{~cm}$ of tree circumference. High volume injections utilized a Turfco model 490 Injector (Turf Industries, Inc., Austin, TX) pressurized with $\mathrm{CO}_{2}$ and connected in a continuous series around the bole with tygon tubing and polyethylene $\mathrm{T}$ injection ports. The ports, inserted into 7$\mathrm{mm}$ holes drilled into exposed root flares approximately 10 to $12 \mathrm{~cm}$ below the soil surface, were used to apply the fungicide at a rate of $3 \mathrm{ml} /$ liter $\mathrm{H}_{2} \mathrm{O} / 6.4 \mathrm{~cm}$ tree diameter at breast height (dbh). Microinjections

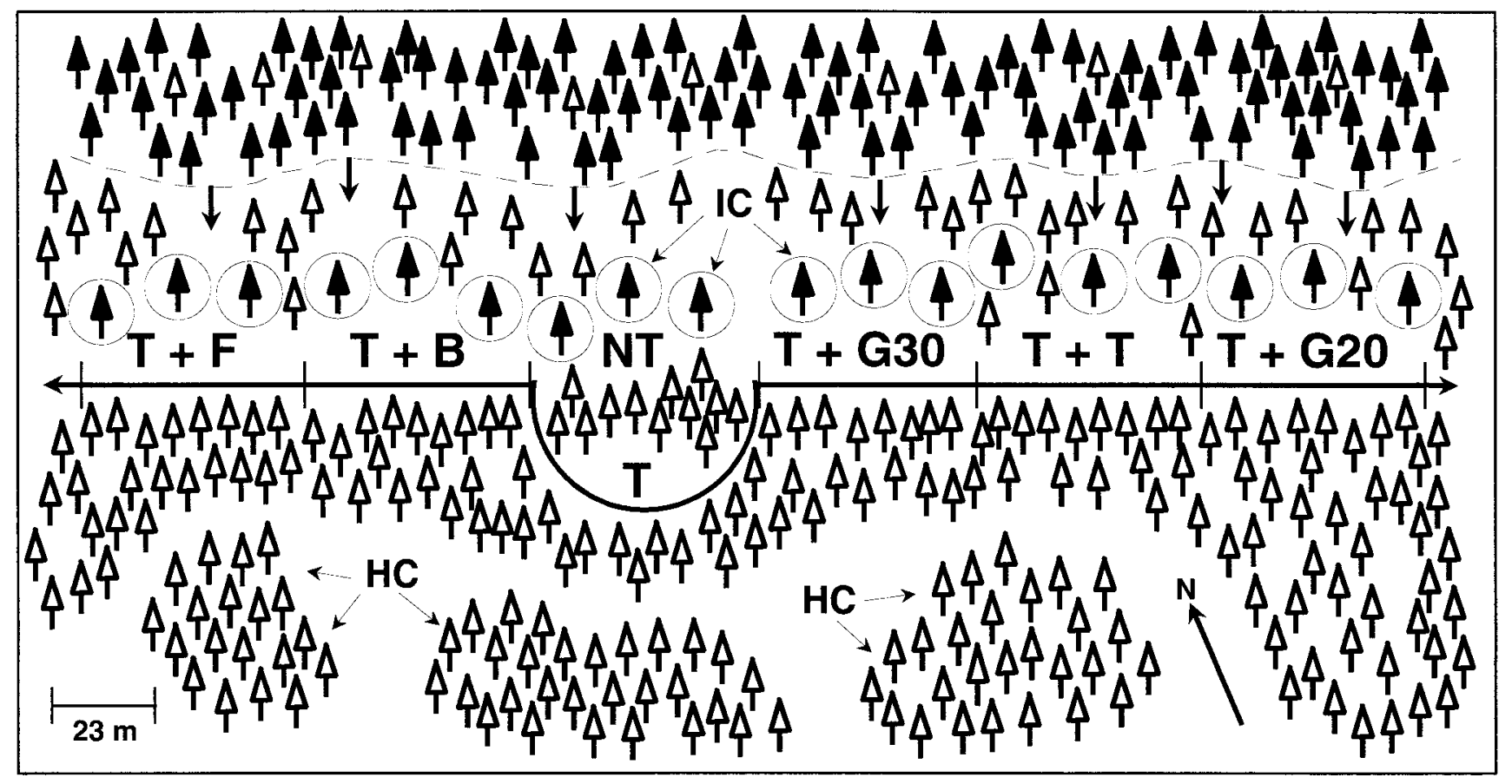

Fig. 1. Experimental design and layout of seven plot treatments plus healthy and inoculated controls in one of three replicates adjacent to an expanding oak wilt infection center. Test trees associated with trench treatments were located just outside of the trench on the side opposite to the infection center. Treatments applied to plots in 1993 included: $\mathrm{HC}=$ healthy controls; IC $=$ inoculated controls (circled); $\mathrm{NT}=$ no trench; $\mathrm{T}=$ trench only; $\mathrm{T}+\mathrm{B}=$ trench + Biobarrier insert; $\mathrm{T}+\mathrm{F}=$ trench + fungicide; $\mathrm{T}+\mathrm{G} 20=$ trench + Geomembrane 20 mil insert; $\mathrm{T}+\mathrm{G} 30=$ trench + Geomembrane 30 mil insert; and $\mathrm{T}+\mathrm{T}$ $=$ trench + Typar insert. Dash line indicates visible front edge of infection center in 1993, and bold arrows indicate direction the front was moving. Open and closed tree symbols indicate asymptomatic and symptomatic trees in 1993, respectively, while circled, closed tree symbols indicate asymptomatic trees inoculated in 1994. 
with experimental ARBORx microinjectors (Tree Technology Systems, Inc., Cheektowaga, NY) applied the fungicide at the rate of $6 \mathrm{ml} / 12 \mathrm{ml} \mathrm{H} \mathrm{H}_{2} \mathrm{O} / 5.1 \mathrm{~cm}$ tree dbh. A second type of small-volume delivery system utilized Mauget microinjectors (J.J. Mauget Co., Los Angeles, CA), applying the fungicide undiluted at $6 \mathrm{ml} / 5.1 \mathrm{~cm}$ $\mathrm{dbh}$. The soil applications were applied at $3 \mathrm{ml} / 6.4 \mathrm{~cm}$ tree dbh in 2-liter aliquots of $\mathrm{H}_{2} \mathrm{O}$ divided and distributed evenly around the drip line of each tree in small holes dug
5 to $10 \mathrm{~cm}$ deep at 3 - to 5-m intervals, depending on crown size, and covered with soil. Healthy control trees that received no treatment were selected well beyond the trench to serve as noninfected and untreated controls.

Inoculations of challenge trees. All treatments were challenged by natural inoculum through root transmission from roots of infected trees along the expanding edge of the infection center. In addition, three trees per plot, located approximately halfway between the trench and the adjacent infection center, were artificially inoculated to provide additional pressure on barrier treatments and to serve as inoculated controls. Trees to be inoculated were cut with an axe into the sapwood on one side of the tree on 5 May 1994, 10 months following trench installation. The wound was immediately filled with a 1- to 2-ml aliquot of a suspension of mixed mycelialconidial inoculum $\left(3.7 \times 10^{6} \mathrm{CFU} / \mathrm{ml}\right)$ prepared from colonies of $C$. fagacearum
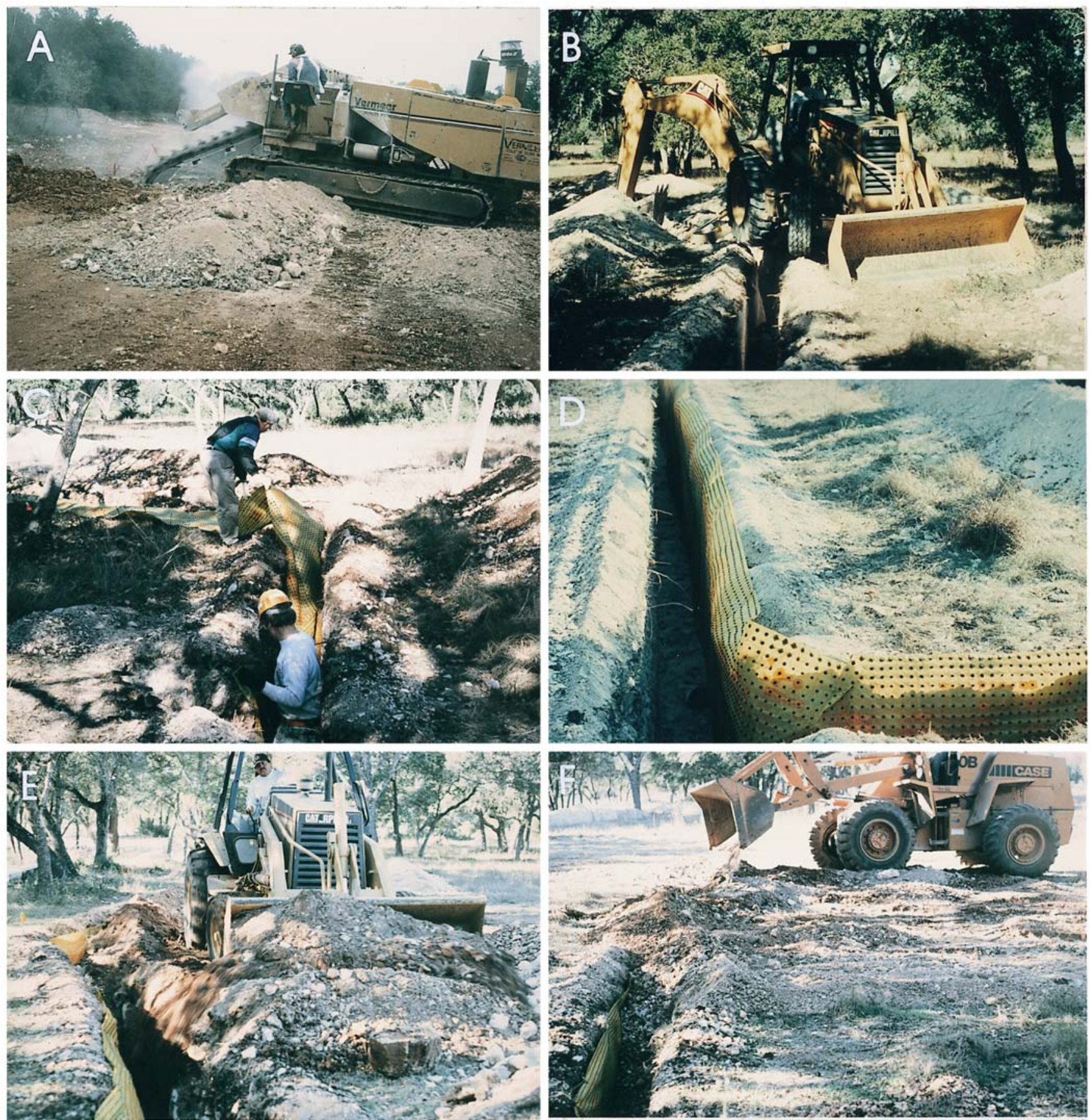

Fig. 2. Installation of insert materials into trenches. A, Trenches were cut using a Vermeer turbo II trencher, removing soil to a depth of $1.51 \mathrm{~m}$. B, Soil and rock not excised by the trencher were removed with a Caterpillar backhoe. $\mathbf{C}, 1.51-\mathrm{m}$-wide trench insert materials (Biobarrier shown) were installed manually into the trench in 15.2- to 30.5-m lengths. D, Inserts were secured in place with $15-\mathrm{cm}$ steel or aluminum pins inserted through the material into the soil at the upper edge of the trench. E, Trenches were backfilled with soil (removed during trenching) using the front scoop of the backhoe tractor. F, Soil used to backfill was leveled with the scoop blade drawn across the top of the trench. 
(strain SHL-TX-36; ATCC 200432), isolated from the adjacent infection center (30), and incubated for 1 week without shaking in $0.5 \%$ neopeptone-glucose broth (26). The inoculum was ground with a blender for 1 to $2 \mathrm{~min}$ within the broth prior to quantitation and inoculation.

Soil excavations of trench inserts. Root growth in relation to trench inserts was assessed the fifth year following challenge inoculations by random spot root excavations in plots of each treatment to sample soil to a maximum depth of $1.5 \mathrm{~m}$ on the inside of the trench for each of the four trench insert types. Determinations were made as to whether root growth occurred over the inserts in cases where the barrier material was buried too deeply below the soil surface. Root growth at the bottom of the trench was assessed only in cases where trench breakouts (symptomatic trees found outside of the trench) occurred in sections with trench inserts and when it was suspected that growth of roots may have occurred under the barrier material. Insert materials also were examined for root contacts and root penetrations in each sampled trench section. The effects of insert materials on root growth were scored based on whether root growth was directionally diverted upon contact with insert materials, exhibited dichotomous branching, grew around insert barriers, was inhibited by chemical action, and whether roots had swollen apices.

Data collections and analysis. Data from test trees within all research plots were collected and evaluated on an annual basis during a 6-year sequential period (1995 to 2000), with the exception of year 5 (1999), when no data were collected. These data were compared against inoculated control trees inside of the trench, healthy control trees well outside of the trench, and infected breakout trees that became infected by root transmission beyond test trees outside of the trench. Trench breakouts, percent tree infection, and percent tree mortality were measured.
The incidence of trench breakouts was noted per $183 \mathrm{~m}$ of barrier within each of three trench segments. The mean distance of symptomatic trees from the trench was recorded when trench breakouts occurred. Crown symptom ratings, percent branch mortality, percent defoliation, and crown light transmission were recorded as indications of disease severity. Crown symptoms were rated using the following scale: $1=$ crown dead, totally defoliated, or with only necrotic leaves attached, 2 = thinning crown with leaves having diagnostic oak wilt symptoms, 3 = crowns containing foliage with chlorosis or reduced leaf size, but lacking diagnostic symptoms of oak wilt, and $4=$ full, healthy crown with no apparent foliar symptoms. Veinal necrosis is considered the most diagnostic foliar symptom of oak wilt in Texas live oaks. Veinal necrosis is often accompanied by marginal necrosis in later stages of leaf symptom development. Crown light transmission, indicating the percentage of total available sunlight passing through the crown, was calculated from lux units recorded with an Extech light meter (Extech Instruments Corp., Waltham, MA) under the crown relative to direct sunlight. Sapwood water content was measured with a Protimeter Digital Timbermaster moisture probe (Protimeter Inc., Commack, NY). Disease severity percentage values were arcsine transformed prior to analysis. Significant differences among means were determined according to Fisher's LSD tests after GLM analysis.

\section{RESULTS}

Trench insert and fungicide barrier tests. During the first 2 years, disease progressed slowly toward the trench from inoculated and naturally infected trees in the adjacent infection center. Only inoculated control trees located inside of containment trenches, used to provide additional challenge to test barriers, expressed diagnostic symptoms of oak wilt during the first year after inoculation. Almost $60 \%$ of inoculated control trees had oak wilt symptoms, and $44 \%$ were dead due to oak wilt after 1 year (Table 1). Inoculated controls had considerable decline in crown density due to effects of the disease on foliage as well as associated decreases in crown symptom ratings and considerable increases in branch mortality the first year (Fig. 3A and B). An appreciable decrease in crown symptom rating and increase in defoliation and branch mortality also occurred in trees within no-trench plots during the first year, but no diagnostic oak wilt symptoms were as yet detected (Fig. $3 \mathrm{~A}$ to $\mathrm{C}$ ).

The advancing front of the infection center moved unimpeded via root transmission into plots lacking trenches (no trench controls) during the second year, although only trees in one of these plots exhibited leaf veinal necrosis. Nevertheless, trees in no-trench control plots developed crown injury at levels that approached those observed in inoculated controls during the first year (Fig. 3A to D). Almost a third of all trees within plots without trenches were infected based on considerable defoliation and crown decline, and almost $14 \%$ mortality was observed in these trees by the end of the second year (Table 1). Diagnostic symptoms were found in leaves on the ground, but there were limited numbers of symptomatic leaves on living trees due to drought conditions during the evaluation. However, inoculated controls developed oak wilt symptoms much more rapidly and had higher disease incidence and severity than trees that become infected by root transmission. Drought conditions that prevailed throughout the summer months during the second evaluation year exacerbated disease development, especially branch death.

The advancing front of the infection center continued to move unimpeded into two no-trench plots in year 3 , resulting in increased incidence of infection and tree mortality relative to year 2 . The occurrence of diseased trees outside of containment

Table 1. Disease progress associated with trench treatments indicated by the incidence of trench breakouts, percent infection, and mortality of test trees during the first four years following inoculations of challenge trees inside containment barriers $^{y}$

\begin{tabular}{|c|c|c|c|c|c|c|c|c|c|c|c|c|c|}
\hline \multirow[b]{2}{*}{ Treatment } & \multirow[b]{2}{*}{$\mathbf{n}$} & \multicolumn{4}{|c|}{$\begin{array}{c}\text { Trench breakouts } \\
\text { Years }\end{array}$} & \multicolumn{4}{|c|}{$\begin{array}{l}\text { Percent symptomatic } \\
\text { Years }\end{array}$} & \multicolumn{4}{|c|}{$\begin{array}{c}\text { Percent mortality } \\
\text { Years }\end{array}$} \\
\hline & & 1 & 2 & 3 & 4 & 1 & 2 & 3 & 4 & 1 & 2 & 3 & 4 \\
\hline Healthy control & 84 & - & - & - & - & 0 & 0 & 0 & 0 & 0 & 0 & 0 & 0 \\
\hline Trench + Typar & 34 & 0 & 0 & 0 & 0 & 0 & 0 & 0 & 0 & 0 & 0 & 0 & 0 \\
\hline Trench + Geo $30 \mathrm{mil}$ & 32 & 0 & 0 & 0 & 0 & 0 & 0 & 0 & 0 & 0 & 0 & 0 & 0 \\
\hline Trench + Biobarrier & 37 & 0 & 0 & 0 & 0 & 0 & 0 & 0 & 0 & 0 & 0 & 0 & 0 \\
\hline Trench only & 28 & 0 & 0 & 0 & 1 & 0 & 0 & 0 & 3.6 & 0 & 0 & 0 & 0 \\
\hline Trench + fungicide & 26 & 0 & 0 & 0 & 1 & 0 & 0 & 0 & 7.7 & 0 & 0 & 0 & 0 \\
\hline Trench + Geo 20 mil & 32 & 0 & 0 & 1 & 3 & 0 & 0 & 9.4 & 12.5 & 0 & 0 & 3.1 & 6.3 \\
\hline No trench & 29 & 0 & [1] & [2] & {$[2]$} & 0 & 31.0 & 41.4 & 48.3 & 0 & 13.8 & 20.7 & 24.1 \\
\hline Inoculated control & 46 & - & - & - & - & 56.5 & 73.9 & 78.3 & 82.6 & 43.5 & 43.5 & 45.7 & 45.7 \\
\hline
\end{tabular}

${ }^{y}$ Field plots were established with trench installation on 27 July 1993, trench insert installations on 13 December 1993, and inoculations of challenge trees within trenches on 5 May 1994. Years 1 to 4 after challenge inoculations correspond to annual data collections from 1995 to 1998 , respectively. Percent values are the portion of test trees exhibiting oak wilt symptoms and mortality; $\mathrm{n}=$ number of test trees per treatment.

${ }^{\mathrm{z}}$ Three replicated plots per treatment. Breakouts refer to the number of plots (out of three) with symptomatic trees beyond test trees positioned immediately outside of barrier treatments. The presence of symptomatic trees beyond test trees within plots containing no trenches is indicated by [ ]. 
trenches (trench breakouts) was not seen in treatment plots with barriers until the third year. A trench breakout was observed only for the thinner, water-impermeable $\mathrm{Ge}$ omembrane 20 insert. However, the incidence of infection among test trees within the trench breakout of this plot was less than $10 \%$, with only $3 \%$ mortality by the end of the third year (Table 1). Infected trees in breakout areas exhibited significantly lower crown ratings and significantly higher branch mortality and defoliation than healthy controls (Fig. 3A and B). The level of disease in inoculated trees increased only slightly the third year, as most of the trees had already been symptomatic (almost 80\%), and tree and branch mortality as well as defoliation appeared to reach a plateau (Table 1, Fig. 3B and C). Approximately $20 \%$ of inoculated trees continued to show a progression of decline but remained alive for the duration of the study.

Differences in disease incidence and disease progress among treatments were greater in the fourth year. Infected trees in breakout areas exhibited significantly lower crown ratings and significantly higher branch mortality and defoliation than healthy controls (Fig. 3A to C). New trench breakouts occurred in trench only and trench + fungicide plots, but no mortality was observed in these plots. No significant difference in disease incidence was found among fungicide treatments within trench + fungicide plots. Therefore, all fungicide application results were combined. No apparent phytotoxicity was observed with any fungicide treatments. Additional trench breakouts also occurred in the Geomembrane 20 plots in year 4 (Table 1), but no breakouts were evident in the other barrier treatments. Disease incidence and severity also continued to increase in the no trench plots. Crown light transmission continued to increase in year 4 due to thinning of crowns, particularly in inoculated controls, no trench, and Geomembrane 20 plots (Fig. 3D).

Treatment plots examined at the end of the fifth year exhibited no significant changes in trench breakouts among treatments from those observed for the fourthyear evaluation. However, treatment effects were well differentiated by the end of the sixth year. No trench breakouts were recorded for the water-permeable trench insert materials, Typar and Biobarrier, nor with the water-impermeable insert Geomembrane 30 (Table 2). Nevertheless, all of the replicate plots containing the waterimpermeable insert Geomembrane 20 had breakouts. Disease incidence was highest $(86 \%)$ in no trench plots, and this value was comparable to inoculated controls. The trench + Geo 20 plots had intermediate levels of tree infection, but the trench + fungicide and trench only plots similarly exhibited low levels of disease incidence, less that half of that found in the trench +
Geo 20 plots. Symptomatic breakout trees were relatively close to the trench (mean distance $=4.1 \mathrm{~m}$; range $=1.5$ to $12.4 \mathrm{~m}$ ) in the trench only and trench + fungicide plots. Symptomatic trees were more dispersed and further from the trench (mean distance $=18.1 \mathrm{~m}$; range $=6.3$ to $43.3 \mathrm{~m}$ ) in the trench + Geo 20 plots.

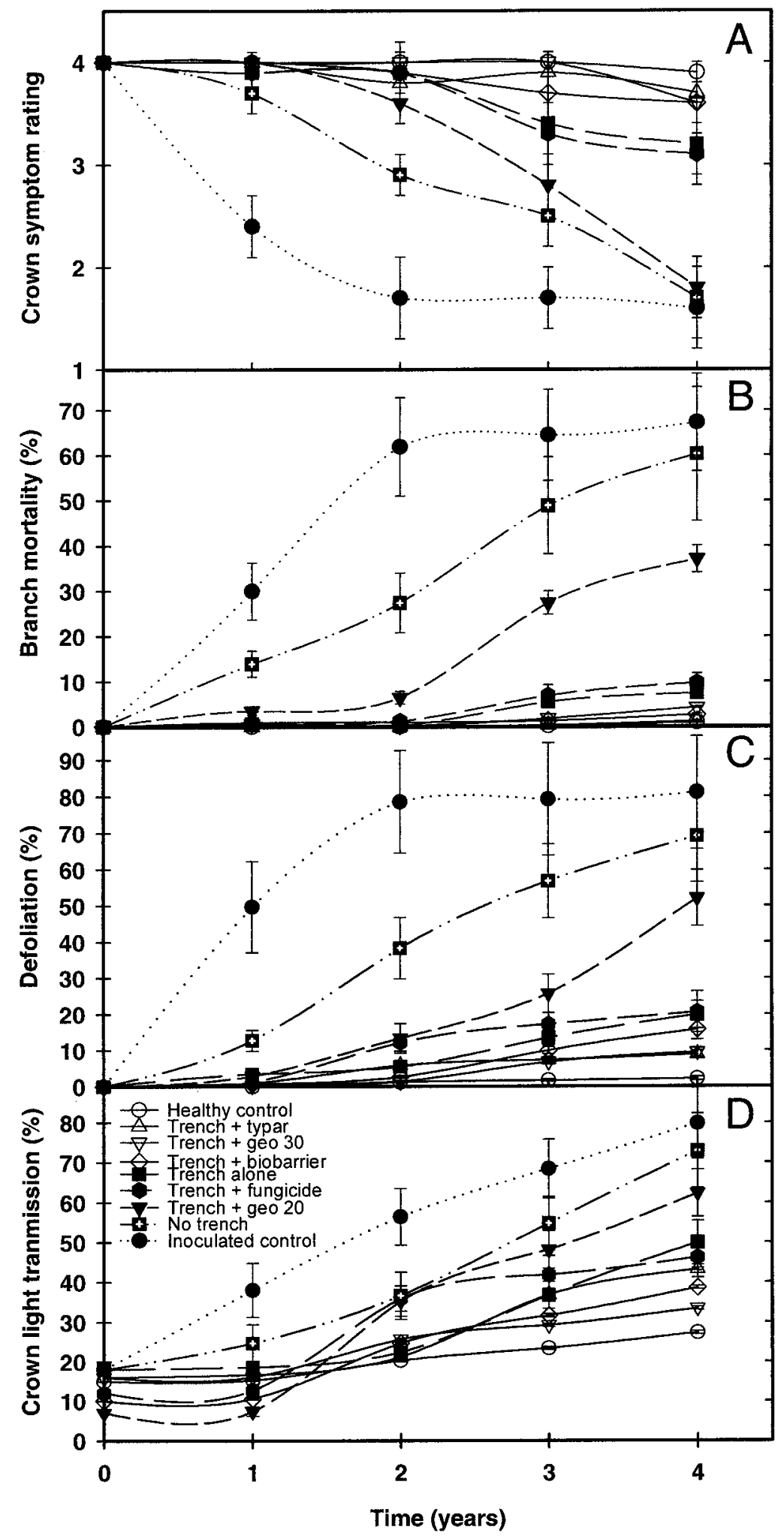

Fig. 3. Changes in disease progress and symptom severity for test trees during the first 4 years following inoculation of challenge trees within treatment plots. Indicators of symptom severity included: A, crown symptom rating on a 1 to 4 scale; $\mathbf{B}$, branch mortality measured as a percentage of major branches that were dead; $\mathbf{C}$, defoliation percentage, a visual assessment of leaf drop relative to healthy trees; and $\mathbf{D}$, crown light transmission indicated by the percentage of ambient light that passed through the crown relative to direct sunlight. Error bars represent standard deviations of means. 
Measures of disease severity were in close agreement with disease incidence in providing clear distinctions after 6 years. Treatment effects on disease severity were highly significant $(F=62.5, P<0.001)$. Crown symptom ratings provided the most reliable indicators of infection status and disease development since diagnostic symptoms were included in this measure of disease severity. Tree mortality was not observed in Typar, Geo 30 mil, and Biobarrier plots. Relatively few trees died in trench only plots $(11 \%)$, but higher mortality occurred in trenched plots with fungicide treatments (15\%) and with Geo 20 inserts $(28 \%)$ (Table 2 ). Tree mortality was about $45 \%$ in no trench plots and in inoculated trees. Branch mortality developed more slowly than other symptoms. Some branch mortality $(<10 \%)$ was found in nonsymptomatic trees in plots with effective barriers to root transmission. However, branch mortality generally correlated with incidence of breakouts, infection, tree mortality, and symptom ratings.

Crown defoliation was the most apparent symptom of oak wilt in latter stages of disease development. Crown light transmission increased proportionally with increased defoliation in medium to largesized trees $(>30 \mathrm{~cm} \mathrm{dbh})$, but branch mor- tality contributed more significantly to increased crown light transmission in smaller trees $(<20 \mathrm{~cm}$ dbh). Many inoculated trees rapidly defoliated and appeared dead, yet some apparently dead trees still had small amounts of living foliage. Crown light transmission underestimated defoliation, as dead leaves on some dying trees tended to remain attached to limbs for prolonged periods of time. Nonsymptomatic trees in plots having trench inserts showed rates of defoliation up to $20 \%$, probably due to the effects of drought immediately prior to the end of the sixth-year evaluation. Defoliation rates were correlated with increasing tree and branch mortality in infected breakout trees in plots with barrier failure. However, defoliation occurred more rapidly than branch mortality in infected breakout trees as disease incidence and disease severity increased.

Soil excavations of trench inserts. When examined after 5 years, roots encountered in the loose backfill soil within trenches were predominantly small adventitious roots less than $2 \mathrm{~cm}$ in diameter. Root contacts occurred with the Typar and Geomembrane inserts of both thicknesses, but root contacts were absent with the Biobarrier insert, perhaps because of the presence of the controlled-release triflu- ralin herbicide (Table 3). Root penetrations were not observed for any trench insert material in spot tests along the full length of the trench, even in situations where trench breakouts occurred. All breakouts were associated with segments where roots grew either over or under the trench insert material. Root growth around the insert materials was only observed with the water-impermeable Geo 20 and Geo 30 materials. Adventitious roots commonly grew through the soil over these insert materials where the inserts were accidentally buried too deeply, generally $<7 \mathrm{~cm}$ below the soil surface. Similarly, roots occasionally grew under the trench in situations where roots contacted the water-impermeable Geo 20 inserts near the bottom of the trench and were diverted downward and under the barrier.

Adventitious roots found in contact with the water-impermeable Geomembrane material of both thicknesses were usually strongly diverted perpendicularly upward, downward, or sideways along the face of the material. Linear growth extended up to $50 \mathrm{~cm}$ or more from the point of root contact with the material, and the roots showed no appreciable dichotomous branching (Table 3). However, roots that came in contact with the water-permeable

Table 2. Effects of trenching, fungicide, and trench insert barriers on root transmission of Ceratocystis fagacearum in live oaks 6 years after inoculations of challenge trees inside containment barriers ${ }^{\mathrm{w}}$

\begin{tabular}{|c|c|c|c|c|c|c|c|c|c|c|}
\hline \multirow[b]{3}{*}{ Treatment } & \multirow[b]{3}{*}{$\mathbf{n}$} & \multicolumn{4}{|c|}{ Disease incidence $^{x}$} & \multicolumn{5}{|c|}{ Disease severity ${ }^{y}$} \\
\hline & & \multirow{2}{*}{$\begin{array}{l}\text { DBH } \\
(\mathbf{c m})\end{array}$} & \multirow{2}{*}{$\begin{array}{c}\text { Trench } \\
\text { breakouts }\end{array}$} & \multirow{2}{*}{$\begin{array}{c}\text { Trees } \\
\text { Symptomatic }\end{array}$} & \multirow{2}{*}{$\begin{array}{l}\text { Distance } \\
\text { from } \\
\text { trench }(m)\end{array}$} & \multirow{2}{*}{$\begin{array}{c}\text { Symptom } \\
\text { rating }^{\mathrm{z}}\end{array}$} & \multicolumn{2}{|c|}{ Mortality (\%) } & \multirow{2}{*}{$\begin{array}{l}\text { Defoliation } \\
(\%)\end{array}$} & \multirow{2}{*}{$\begin{array}{c}\text { Crown light } \\
\text { transmission } \\
(\%)\end{array}$} \\
\hline & & & & & & & Tree & Branch & & \\
\hline Healthy control & 84 & 25.4 & - & 0 & - & $3.94 \mathrm{a}$ & 0 & $1.5 \mathrm{e}$ & $2.6 \mathrm{~g}$ & $28.3 \mathrm{~g}$ \\
\hline Trench + Typar & 34 & 23.6 & 0 & 0 & - & $3.56 \mathrm{~b}$ & 0 & $2.1 \mathrm{e}$ & $9.7 \mathrm{fg}$ & $45.7 \mathrm{de}$ \\
\hline Trench + Geo $30 \mathrm{mil}$ & 32 & 23.3 & 0 & 0 & - & $3.44 \mathrm{bc}$ & 0 & $6.3 \mathrm{~d}$ & $10.2 \mathrm{fg}$ & $36.0 \mathrm{f}$ \\
\hline Trench + Biobarrier & 37 & 27.6 & 0 & 0 & - & $3.41 \mathrm{bc}$ & 0 & $4.3 \mathrm{e}$ & $16.4 \mathrm{ef}$ & $39.9 \mathrm{ef}$ \\
\hline Trench only & 28 & 35.6 & 1 & $4(14.3)$ & 4.9 & $3.21 \mathrm{c}$ & 10.7 & $11.6 \mathrm{de}$ & $23.4 \mathrm{e}$ & $52.1 \mathrm{~d}$ \\
\hline Trench + fungicide & 26 & 31.6 & 1 & $7(26.9)$ & 3.2 & $3.19 \mathrm{c}$ & 15.4 & $19.9 \mathrm{~d}$ & $24.6 \mathrm{e}$ & $47.3 \mathrm{de}$ \\
\hline Trench + Geo 20 mil & 32 & 28.2 & 3 & $18(56.3)$ & 18.1 & $2.25 \mathrm{~d}$ & 28.1 & $40.1 \mathrm{c}$ & $55.8 \mathrm{~d}$ & $64.7 \mathrm{c}$ \\
\hline No trench & 29 & 35.5 & [3] & $25(86.2)$ & - & $1.69 \mathrm{e}$ & 44.8 & $65.0 \mathrm{~b}$ & $69.4 \mathrm{c}$ & $75.1 \mathrm{~b}$ \\
\hline Inoculated control & 46 & 34.8 & - & $40(87.0)$ & - & $1.67 \mathrm{e}$ & 45.7 & $69.6 \mathrm{~b}$ & $81.2 \mathrm{~b}$ & $81.2 \mathrm{ab}$ \\
\hline Infected breakouts & 50 & 30.0 & - & $50(100)$ & - & $1.34 \mathrm{f}$ & 66.0 & $80.8 \mathrm{a}$ & $95.1 \mathrm{a}$ & $87.3 \mathrm{a}$ \\
\hline
\end{tabular}

${ }^{\text {w }}$ Data taken in 2000, 6 years after challenge inoculations, from three replicated plots per treatment, with the exceptions of control and breakout trees. Plots were established with trench installation on 27 July 1993, trench insert installations on 13 December 1993, and inoculations of challenge trees on 5 May 1994; $\mathrm{n}=$ number of test trees per treatment.

$x$ Disease incidence in trees outside of barrier treatments. Breakouts refer to the number of plots (out of three) with symptomatic trees beyond the barrier, or plots indicated by [ ] where no barrier existed. Values in parentheses are the percentage of infected trees within all plots for each treatment. Distances refer to the mean distances of symptomatic trees from the trench in breakout plots.

${ }^{y}$ Percent values were arcsine transformed prior to analysis, although values presented are actual percentages. Means with different letters within each column are significantly different $(P<0.001)$ according to Fisher's LSD tests.

${ }^{\mathrm{z}}$ Crown symptom ratings used the following scale: $1=$ crown dead, totally defoliated, or with only necrotic leaves attached; $2=$ thinning crown with leaves having diagnostic oak wilt symptoms, including veinal chlorosis or veinal necrosis; $3=$ crowns containing foliage with chlorosis or reduced leaf size, but lacking diagnostic symptoms of oak wilt; and 4 = full, healthy crown with no apparent foliar symptoms.

Table 3. Root growth in the vicinity of trench insert materials 5 years after challenge inoculations ${ }^{2}$

\begin{tabular}{lccccccc}
\hline Trench insert & $\begin{array}{c}\text { Root } \\
\text { contact }\end{array}$ & $\begin{array}{c}\text { Root } \\
\text { penetration }\end{array}$ & $\begin{array}{c}\text { Dichotomous } \\
\text { branching }\end{array}$ & $\begin{array}{c}\text { Directional } \\
\text { diversion }\end{array}$ & $\begin{array}{c}\text { Growth around } \\
\text { trench insert }\end{array}$ & $\begin{array}{c}\text { Growth } \\
\text { inhibition }\end{array}$ & $\begin{array}{c}\text { Swollen } \\
\text { apices }\end{array}$ \\
\hline Typar & + & - & + & + & - & - & - \\
Biobarrier & - & - & - & - & - & + & + \\
Geo 20 mil & + & - & - & ++ & + & - & - \\
Geo 30 mil & + & - & - & ++ & + & - & -
\end{tabular}

\footnotetext{
${ }^{z}$ Scoring of effects and interactions with root growth: (-) no effect or interaction; (+) moderately positive effect or interaction; (++) strong effect or inter-
} action. 
Typar insert were diverted only slightly ( $<20 \mathrm{~cm}$ length) from the point of contact and tended to exhibit considerable dichotomous branching. Adventitious roots coming in contact with trifluralin-treated soil around Biobarrier slow-release pellets showed some effects of herbicide exposure, including reduced growth (growth inhibition) relative to nonherbicide treatments, swollen apices, and greatly attenuated root branching. None of the other insert materials caused significant growth inhibition of roots or swollen apices.

\section{DISCUSSION}

Small adventitious roots $<2 \mathrm{~cm}$ in diameter commonly formed from the ends of lateral live oak roots severed by trenching. These small roots grew and accumulated within the trench in the loose backfill soil, which favored root growth relative to the hard, compact undisturbed soil. The process of root regeneration within trench backfill soil took at least 3 to 4 years after trenching before it was sufficient for root grafting. The slow growth of regenerating roots was attributed to the dry edaphic conditions in the semiarid Texas Hill Country.

Interactions between newly regenerated adventitious roots and trench-insert materials appear to explain the cause of trench breakouts. Root contacts occurred with all insert materials except Biobarrier, but no root penetrations were observed with any insert material. This implied that trench breakouts were due to root growth around these physical barriers. Biobarrier chemically inhibited root growth with the herbicide trifluralin. Root diversion by the water-permeable Typar was limited by dichotomous branching of root apices, which reduced linear elongation. Dichotomous branching may be a growth response of roots receiving moisture through the barrier. However, the water-impermeable inserts (Geo 20 and Geo 30) diverted roots to the upper and lower edges of inserts where root grafting may occur. Root grafting can occur either because the insert was buried too deeply in the trench (soil above insert) or because the soil depth to bedrock is greater than the width of the insert (soil below insert). Several instances were discovered where short sections of the Geo 20 material were buried too deeply, and these sections were in very close proximity to trench breakouts.

Trench inserts did not significantly improve on trenches alone as barriers to root transmission during the first 3 years after trench installation, but certain inserts did improve trench effectiveness beyond the third year. The water-impermeable inserts appeared to direct root growth around these barriers, potentially leading to root grafting. Although Geomembrane is a tough, heavy, and durable material that serves as an excellent barrier to root penetration owing to its pliability and resistance to puncture, these properties contribute to root diversion and difficulty of installation. The thicker Geomembrane $30 \mathrm{mil}$ also diverted root growth, but no breakouts were observed. With Biobarrier, roots generally do not come in contact with the fabric itself because root growth is inhibited in the herbicide-treated zone immediately adjacent to the fabric. The use of the herbicide trifluralin (Dow Elanco, Indianapolis, IN), which specifically prevents root-tip cell division, in controlled-release pellets has several advantages, including very low water solubility, negligible groundwater contamination, low minimum effective concentrations $(<10 \mathrm{ppm})$, rapid initial release rates, long activity time, and lack of uptake by tree roots and translocation within the plant $(8,9,11)$. The restricted movement of trifluralin in soil due to very low water solubility and strong adsorption to soil particles limits the distance of herbicidal activity to $<5 \mathrm{~cm}$ from the pellets $(8,14,17)$. Thus, there are very limited adverse effects on roots not immediately adjacent to the barrier.

The results here suggest that Typar performed as well as Biobarrier in providing sufficient protection against root penetrations without the need for the additional (chemical) barrier provided by the trifluralin. The Typar material also is available in three thicknesses $(1 \times, 1.5 \times, 2 \times$, or 4,6 , and 8 oz., respectively), which provide increasing levels of resistance to root penetrations as needed. Both Biobarrier and Typar are composed of lightweight polypropylene and were easily installed, but unlike the heavy Geomembrane material (polyethylene), both degrade with prolonged exposure to sunlight. Typar is generally priced 70 to $80 \%$ less than Biobarrier at comparable widths and thicknesses.

The results presented here strongly suggest that fungicide injections are ineffective in preventing root transmission of the oak wilt fungus, confirming previous observations (3). The ineffectiveness of fungicide injections is largely explained by the predominantly upward movement of triazole fungicides such as propiconazole (Alamo) in the vascular system of injected plants (19). Consequently, insufficient quantities of fungicide are translocated down into the root system to prevent viable inoculum from being translocated through root grafts into adjacent noninfected trees. Applications of propiconazole as a chemical control to prevent root transmission could be modified so that the material is introduced at the distal ends of the root system, as with soil application treatments. The most effective results with propiconazole are achieved when it is applied annually as a soil drench over several consecutive years (31).

Improvements in trenching methods are needed by oak wilt suppression programs in all states affected by this disease. Installing trench inserts into primary trenches to preclude breakouts due to root regrafting should significantly reduce incidences of oak wilt root transmission. Water permeable trench inserts provide cost-effective insurance against breakouts because they may be installed at a fraction (less than $10 \%$ ) of the cost of expensive backup trenches that are required when primary trenches fail. Developing methods for reducing overland transmission of $C$. $f a-$ gacearum and improving on existing methods for optimizing trench placement $(5,6,10)$ also would provide useful tools to facilitate control of this malady.

\section{ACKNOWLEDGMENTS}

We thank Steven P. Bartlett, Bradley Development, Circle $\mathrm{C}$ Land Corporation, for providing land for this work. We thank Carey Cornelius, Circle C Ranch landscaping crewmen, and Lynn Silverman, who assisted in the installation of research plots for this study. We particularly appreciate the financial expenses incurred by Bradley Development in association with the installation and backfilling of the test trench, brush maintenance around test trees, and assistance provided in the use of heavy excavation equipment for collecting root samples and for subsurface examinations of trench insert performance within trenches. We thank Carl Schattenberg, former forester for the City of Austin in Travis Co., TX, who provided initial contacts and assistance in locating suitable sites for this study. We appreciate the donations of trench insert materials from Reemay Inc. and Raven Industries. We are grateful to Jerry A. Dunaway, who provided assistance in the installation of trench insert materials for this study. We are indebted to Ciba (Novartis), J. J. Mauget Co., Inc., and Monterey Chemical Co. for donating materials for the fungicide applications. We thank James B. Briggs for assistance in root-flare soil excavations and high-volume fungicide applications. Finally, we acknowledge Lisa F. Wilson and Bryce Burke for assistance in data collections.

\section{LITERATURE CITED}

1. Anonymous. 1942. Oak wilt: A fungus disease. What's new in farm science. Wisc. Agric. Exp. Stn. Bull. 455:75-76.

2. Appel, D. N. 1995. The oak wilt enigma: Perspectives from the Texas epidemic. Annu. Rev. Phytopathol. 33:103-118.

3. Appel, D. N., and Kurdyla, T. 1992. Intravascular injection with propiconazole in live oak for oak wilt control. Plant Dis. 76:1120-1124.

4. Billings, R. F., Gehring, E. H., Cameron, R. S., and Gunter, J. T. 2001. Current practices in managing oak wilt: Federal cost share programs, trenching, chemical injection, and the Texas suppression program. Pages 117-129 in: Shade Tree Wilt Diseases. Proceedings from Wilt Diseases of Shade Trees: A National Conference. Cynthia L. Ash, ed. American Phytopathological Society, St. Paul, MN.

5. Bruhn, J. N., and Heyd, R. L. 1992. Biology and control of oak wilt in Michigan red oak stands. J. Appl. For. 9:47-51.

6. Bruhn, J. N., Pickens, J. B., and Stanfield, D. B. 1991. Probit analysis of oak wilt transmission through root grafts in red oak stands. For. Sci. 37:28-44.

7. Buechner, H. K. 1944. The range vegetation of Kerr County, Texas, in relation to livestock and white tailed deer. Am. Midl. Nat. 31:697743.

8. Burton, F. G., Cataldo, D. A., Van Voris, P., Skiens, W. E., Griggs, R. D., Decker, O. D., Adriano, D. C., and Murphy, C. E. 1989. Field evaluation and performance specifications of a long-term controlled-release herbicide de- 
livery system for multiple-year control of root growth. Pages 277-278 in: Proc. Int. Sympos. Controlled Release Bioactive Materials, 16th. R. Pearlman and J. A. Miller, eds. American Chemical Society, Chicago, IL.

9. Burton, F. G., Skiens, W. E., Cline, J. F., Cataldo, D. A., and Voris, P. V. 1986. A controlled-release herbicide device for multipleyear control of roots at waste burial sites. J. Control. Rel. 3:47-54.

10. Carlson, J. C., and Maring, A. J. 1996. Lake States woodlands oak wilt management-What are the options? Univ. Wisc. Coop. Ext. Pub. G 3590 .

11. Cline, J. F., Cataldo, D. A., Skiens, W. E., and Burton, F. G. 1983. Biobarriers used in shallow burial grounds stabilization. Nucl. Technol. 58:150-153.

12. Davies, C. S. 1992. Environmental management of oak wilt disease in central Texas. Environ. Manag. 16:323-333.

13. Dewers, R. S. 1971. Shade tree evaluation. Texas Agric. Ext. Serv. Fact Sheet L-958.

14. Dosskey, M. G., Adriano, D. C., Murphy, C. E., and Corey, J. C. 1991. Effectiveness of a slow-release herbicide system for control of root intrusions into buried hazardous waste. Hazard. Waste Mater. 8:293-301.

15. Gehring, E. H. 1995. Evaluation of suppression project treatments. Pages 147-154 in: Oak wilt perspectives: The proceedings of the national oak wilt symposium. David N. Appel and Ronald F. Billings, eds. Information Development Inc., Houston, TX.

16. Gibbs, J. N., and French, D. W. 1980. The transmission of oak wilt. U.S. Dep. Agric. For. Serv. Res. Pap. NC-185.

17. Helling, C. S. 1976. Dinitroaniline herbicides in soils. J. Environ. Qual. 15:1-14

18. Himelick, E. B., and Fox, H. W. 1961. Experimental studies on control of oak wilt disease. Ill. Agric. Exp. Stn. Tech. Bull. 680.
19. Kuck, K. H., and Scheinpflug, H. 1986. Biology of sterol-biosynthesis inhibiting fungicides. Pages 65-96 in: Chemistry of Plant Protection. Vol. 1. Sterol Biosynthesis Inhibitors and Anti-feeding Compounds. G. Haug and H. Hoffmann, eds. Springer-Verlag, Berlin.

20. MacDonald, W. L., and Hindal, D. F. 1981. Life cycle and epidemiology of Ceratocystis. Pages 113-144 in: Fungal Wilt Diseases of Plants. M. E. Mace and A. A. Bell, eds. Academic Press, New York.

21. Martin, C. W., Maggio, R. C., and Appel, D. N. 1989. The contributory value of trees to residential property in the Austin, Texas metropolitan area. J. Arboric. 15:72-76.

22. Muller, C. H. 1951. The significance of vegetative reproduction in Quercus. Madroño 11:129-137.

23. Tainter, F. H. 1995. Host $\times$ parasite interactions. Pages 47-53 in: Oak wilt perspectives: The proceedings of the national oak wilt symposium. David N. Appel and Ronald F. Billings, eds. Information Development Inc., Houston, TX

24. Taubenhaus, J. J. 1934. Live oak disease at Austin, Texas. Tex. Agric. Exp. Stn. Annu. Rep. 47:97-98

25. Taubenhaus, J. J. 1935. Live oak disease at Austin, Texas. Tex. Agric. Exp. Stn. Annu. Rep. 48:99-100.

26. Waksman, G. 1991. Purification and characterization of two endo- $\beta$-1,4-D-glucanases from Sclerotinia sclerotiorum. Biochim. Biophys. Acta. 1073:49-55.

27. Wilson, A. D. 1995. Future direction of USDA Forest Service oak wilt research. Pages 181-186 in: Oak wilt perspectives: The proceedings of the national oak wilt symposium. David N. Appel and Ronald F. Billings, eds. Information Development Inc., Houston, TX.

28. Wilson, A. D. 2000. New methods, algorithms, and software for rapid mapping of tree positions in coordinate forest plots. U.S. Dep. Agric., For. Serv., South. Res. Stn., Res. Pap. SRS-19.

29. Wilson, A. D. 2001. Oak wilt: A potential threat to southern and western oak forests. J. For. 99:4-11

30. Wilson, A. D., and Forse, L. B. 1997. Sensitivity of Texas strains of Ceratocystis fagacearum to triazole fungicides. Mycologia 89:468-480.

31. Wilson, A. D., and Lester, D. G. 1995. Application of propiconazole and Pseudomonas cichorii for control of oak wilt in Texas live oaks. Fungic. Nematicide Tests 50:393.

32. Wilson, A. D., and Lester, D. G. 1996. Preliminary evaluation of trench inserts as barriers to root transmission for oak wilt control in Texas live oaks. (Abstr.) Phytopathology $86: \mathrm{S} 38$

33. Wilson, A. D., and Lester, D. G. 1996. Assessment of trench inserts as barriers to roo transmission for control of oak wilt in Texas live oaks. Biol. Cult. Tests 11:46.

34. Wilson, A. D., and Lester, D. G. 1997. Subsequent tests of trench inserts as barriers to root transmission for control of oak wilt in Texas live oaks. Biol. Cult. Tests 12:63.

35. Wilson, A. D., and Lester, D. G. 1999. Incidence of trench breakouts following applications of trench insert barriers to control root transmission of Ceratocystis fagacearum in Texas live oaks. Biol. Cult. Tests 14:65.

36. Wilson, A. D., and Lester, D. G. 2001. Trench inserts improve trenches for long-term control of oak wilt. (Abstr.) Phytopathology 91:S95.

37. Wilson, A. D., Lester, D. G., and Edmonson, R. E. 2000. Live oaks, new hosts for Odontocynips nebulosa Kieffer (Hymenoptera: Cynipidae) in North America. Proc. Entomol. Soc. Wash. 102:360-373.

38. Young, R. A. 1949. Studies on oak wilt, caused by Chalara quercina. Phytopathology $39: 425-441$. 